\title{
Ocular Microbiota
}

Taha AYYILDIZ1

${ }^{1}$ Department of Ophthalmology, Medical Faculty, Ahi Evran University, Kırşehir, Turkey.

\section{SUMMARY}

One of the most prominent of recent developments is the understanding of human microbiota. Microbiota is a group of microbes settled in a specific area, while microbial describes the total genome of these bacteria. The 10 trillion germs, equivalent to 10 times the total number of cells in the human body, live only in the intestines. The ocular surface is in constant contact with the external environment and has been shown to have a unique flora. The diversity, detection methods, and influence of this fluorophore on ocular immunity, personality, and extrinsic factors have been investigated and improved. Specific treatment of patients, planning of systemic and topical antibiotics, and perhaps ocular fora transplantation are the aims of future studies.

Key words: Ocular microbiota, ocular surface, microbiologic analyses

\section{INTRODUCTION}

Various mucosal surfaces such as the gastrointestinal tract, oral mucosa, and respiratory tract have been colonized by microorganisms. Changes in microbiology may lead to infection and inflammation (1-3). The ocular surface includes mucosal surfaces such as bulbar conjunctiva, palpebral conjunctiva, and conjunctival fornices. Similarities and differences with other mucosal flora of the ocular surface are under investigation (4).

It is important to define the ocular surface microbiology because infections such as endophthalmitis and infectious keratitis arise from the ocular surface. Factor detection is challenging, and culture positivity is below 60\% (5,6). Traditional bacterial culture methods have been shown to have a culture-positive postoperative endophthalmitis of 50\%-70\% $(7,8)$. However, a new method called biome representational in slico karyotyping (BRISK), which is a metagenomic method of analyzing DNAbased life forms, has shown torque teno virus (TTV) positivity in all culture-negative endophthalmitis (9). This suggests that TTV is a member of the ocular surface flora and bacterial and viral members of the ocular surface flora should be extensively investigated.

Only a subspecies design could be developed in studies conducted on ocular surface flora using traditional culture methods $(10,11)$. Significant differences were found between the results of microbiological analysis of ocular fluorescence and results of conventional culture methods using metagenomic approaches (12-14). In a study using traditional culture methods, only Staphylococcus and Bacillus species were detected. The study showed that the application of 165 rDNA gene polymerase chain reaction (PCR) method could detect five subcapsules including bacteria that could not be cultured (13). Dong et al. found that 59 species of bacteria were present when administering 165 rDNA gene sequencing to the ocular surface (12). Although the diversity of ocular microbiotics has been shown in these studies, the disadvantages are the inadequate number of patients and the inability to detect factors such as viruses and fungi. In another study on asymptomatic volunteers based on viral PCR, herpes simplex virus 1, hepatitis B virus, and even hepatitis C virus were detected in tears (15). This suggests 
that ocular surface viruses are residents of ocular flora. Hence, it is important that only the ocular flora analysis be done on the bacteria that may be missing.

This review explored traditional culture, 165 rDNA gene qPCR and sequencing, and BRISK methods used for ocular flora detection.

\section{METHODS}

\section{Traditional culture method}

The microbiota cultured on the ocular surface can be determined using swab samples from conjunctiva, capsules, and tears (16-19). Sticks of cotton or calcium alginate may be used for conjunctival swab specimens. Generally, after wetting, the stick is driven toward lower conjunctival fornix or upper conjunctival fornix and then enriched with vitamins and hematin, brain heart infusion agar, thioglycolate agar, chocolate agar, bloody agar, Sabouraud agar (for mushroom), Drigalski agar (for Enterobacteria and some fermentation-negative enteric bacilli isolation and differentiation), Thayer-Martin agar (isolation of selective Neisseria species), Schaedler or phenylethyl alcohol blood agar (for obligatory anaerobic bacteria), kanamycin (for gram-negative bacteria), eosin methylene blue, or MacConkey agar-vancomycin blood agar (isolation of obligatory anaerobic gram-negative bacilli).

The overall conclusion is that coagulase-negative staphylococci are the most common bacteria isolated from the conjunctiva, cap, or tears and are positive in about half of the cases (16-18). The next most common isolated microorganisms are Propionibacterium and diphtheroid bacteria (mostly Corynobacterium). Culture negativity varies between $9 \%$ and $87 \%$ in conjunctival swabs and $0 \%$ and $48 \%$ in lid swabs $(11,18,20,21)$. The differences are thought to be influenced by sample collection, transport, and culture conditions. A study conducted in India, demonstrated a twofold increase in the frequency of detection of $\mathrm{S}$. epidermidis and $\mathrm{S}$. aureus in conjunctival swab samples taken immediately after $8 \mathrm{~h}$ of sleep (22). It has been shown that colonies per swab are mostly below 80,200 , and 10 in conjunctival, valvular, and tear cultures, respectively $(21,23,24)$.

\section{DNA Purification}

Genomic conjunctival swabs of the eye are made using the DNeasy blood and tissue kit (Qiagen, Inc., Venlo, the Netherlands). The DNA is put into $30 \mu \mathrm{L}$ of elution buffer and then stored at $-20^{\circ} \mathrm{C}$. The DNA analysis is performed using the Qubit dsDNA HS Assay kit (Thermo Fisher Scientific, MA, USA). Next, the 165 metagenomic analysis or BRISK method is used.

\section{TTV Quantitative PCR}

Pan bacterial PCR analysis is performed using 165 ribosomal RNA polymers (DNA Technologies, (A, USA).9 The primer sequences used are 5'-GAGGAAGGTGGGGATGACGT-3 'and 5'-AGGCCCGGGAACGTATTCAC-3'. HotStarTaq DNA polymerase is used for PCR. $100 \mathrm{ng}$ of genomic DNA is used for each reaction. The master mix contains $10 \times$ buffer, Taq polymerase, deoxynucleotide triphosphate, and primers. This mixture is treated for 5 min with 8-methoxypsoralen $(25 \mu \mathrm{g} / \mathrm{mL})$ and ultraviolet radiation (Bio-Rad GS gene linker, ultraviolet chamber; Bio-Rad Laboratories Inc., (A, USA). Amplification is done using the MasterCycler gradient (Eppendorf, Hamburg, Germany). The cycle includes 10 min of denaturation at $94^{\circ} \mathrm{C}, 30$ cycles of denaturation at $45^{\circ} \mathrm{C}$ for $30 \mathrm{~s}$, a $30-s$ cohesion at $58^{\circ} \mathrm{C}$ and $1-$ min synthesis at $72^{\circ} \mathrm{C}$. The final extension is $10 \mathrm{~min}$ at $72^{\circ} \mathrm{C}$.

The PCR mix contains $0.8 \mu \mathrm{L}$ forward and reverse primers $(0.4$ $\mu \mathrm{L}$ each), $10 \mu \mathrm{L}$ ABsolute Blue qPCR SYBR low ROX Mix (Thermo Fisher Scientific), and $1 \mu \mathrm{L}$ unmixed genomic DNA. The 165 DNA $P C R$ analysis was performed with 8-methoxypsoralen without the master mix template and with 5 min of treatment with ultraviolet. The final reaction volume is $20 \mu \mathrm{L}$. At the end of the process, $1 \times 10^{1}$ to $10^{8}$ copies per milliliter are obtained with the corresponding plasmid (16S, TTV, and actin) on specific regions of the complementary DNA of the cloned gene. Quantitative $P C R$ routinely identifies 10 copies $/ \mathrm{mL}$ of the sample in each complementary control DNA. The process is completed after $2 \mathrm{~min}$ at $50^{\circ} \mathrm{C}$ and $10 \mathrm{~min}$ at $95^{\circ} \mathrm{C}$, and then $15 \mathrm{~s}$ at $95^{\circ} \mathrm{C}$ and $1 \mathrm{~min}$ at $60^{\circ} \mathrm{C}$

BRISK

BRISK is a DNA sequencing technique (25). The total DNA sample is divided into 33 fragments around the DNA sequences of type 2b DNA restriction enzyme BsaXI and ACNNNNNCTCC. These 33 fragments are multiplexed in a multiple parallel DNA sequencing 
platform. Each sequence frame includes $>3 \times 10^{7}$ sequences per sample or $>1 \times 10^{6}$ sequences per sequence. Each sequence is compared with the registered samples in the database. All human sequences are mapped. The nonhuman sequences are also compared with the bacterial, parasite, fungal, and viral sequences recorded in the database.

\section{Contact lens-ocular microbiota association}

Various studies have mostly focused on cultivating bacteria that stick on contacts $(26,27)$. Many different polymer contact lenses are in daily use. Some are disposable on a daily basis, while some are long-lasting contact lenses, which can be retained for a period of 1 month. The bacterial cultures most commonly performed in contact lens wearers were coagulase-negative staphylococci, Propionobacterium, and Corynebacterium. No difference was detected in terms of different contact lens polymers and usage patterns. Kültür negatiflik oranı da \%9-84 arasında değişmektedir $(26,27)$. The participant was positive for approximately 123 colonies after removing contact lenses and washing the hands with tap water. Touching with the fingers significantly reduced the number of germs on the lens (28). In asymptomatic contact lens users, A study of more than 300 colonic bacilli per lens showed that the removal of contact lens under aseptic conditions in asymptomatic contact lens users might not be effective (29).

A study on microbiotics of conjunctiva and eyelids of long-term contact lens users showed that the conjunctiva and flap flora remained unchanged, but colonization with pathogenic bacteria such as gram-negative bacilli was found on these two surfaces (21). On the contrary, daily contact lens wearers showed an increased incidence of coagulase-negative staphylococcal colonization in conjunctiva and eyes. A study evaluating conjunctival lenses of old lens wearers, new lens wearers, and non-wearers demonstrated no difference in the other two groups of older lens users with increased bacterial colonization (30).

\section{Age-microbiota association}

The evaluation of the conjunctival culture samples taken immediately after birth of the newborns revealed that the bacterial composition was similar to that of the cervix (31-33). A birth through a cesarean section was examined for bacteria immediately after birth. However, S. epidermidis, E. coli, and S. aureus were observed most frequently in conjunctival swabs made 2 days later (31-33). In another study evaluating conjunctival lid swabs of children aged 8-14 years, the culture positivity was found to be $36 \%$ in conjunctival swabs and $54 \%$ in valvular swabs, suggesting that the composition resembled that in adults (34).

\section{Comparison of ocular microbiota with other mucosal surfaces}

Oral cavity has a wide range of microbiota diversity. Less than 100 colonies are observed in microliters of tears, whereas in saliva this number is around $10^{7}-10^{8}$ (24). The most common bacteria found in oral cavity cultures are Streptococcus, Actinomyces, Veillonella, and Bacteroides (35). In a study in which swabs from the external auditory canal were cultured, the most frequently identified bacteria were staphylococci (S. auricularis), followed by Corynebacteria (36).

Given the wide variety and number of flora in the oral cavity and intestines, it can be concluded that the number and variety of ocular surface flora are low. Also, the bacterial density cultured from the conjunctival swabs is also less than that in the flap swabs.

Relation between ocular microbiota and ocular surface disease

Ocular microbiota may also be altered because lactotransferrin, lysozyme, polymeric immunoglobulin receptor, and lacritin have bactericidal components in tears, and the tear composition changes in the dry eye. Some studies have shown a more intense bacterial burden in the eyes of patients with Sjogren's syndrome than in the eyes of healthy volunteers $(13,37)$. Genetic analyses may reveal details of ocular surface problems and ocular microbiota associations.

Relation of ocular immunity with ocular microbiota Commensal microbes on the mucosal surfaces such as the intestine prevent the colonization of pathogenic microbes (38). However, this is not the case for ocular flora because the ocular surface is paucibacterial. Therefore, the effect of ocular fluorosis on ocular surface preservation is different from that on other mucosal surfaces. Although ocular microfilaments are thought to inhibit the 
colonization of pathogenic agents by activating local immunity, the lack of number and diversity of ocular flora suggests that immunodetection mechanisms may be inadequate.

Immunoglobulin A $(\lg A)$ is the main antibody of the ocular surface (39). IgA also exhibits antiinflammatory activity by neutralizing viruses and bacteria, as well as stimulating interleukin 10 release and affecting maturation of dendritic cells (40). IgD and IgM antibodies are first carried on the surface of bone marrow $B$ lymphocytes, and other antibodies achieve somatic hypermutation and class exchange pathways in the germinal centers of secondary lymphoid tissues (41). The IgA performs class exchange in two distinct ways: T-lymphocyte-dependent and T-lymphocyteindependent (42). The T-lymphocyte-dependent pathway is through the interaction of antigen-specific B lymphocytes with CD4+ T lymphocytes. This interaction occurs in the eye conjunctiva and lacrimal glands (43). It is important for normal rats to reach $\lg A$ and IgM levels of germ cell-free rats in the lacrimal glands 4 weeks after exposure to environmental factors, suggesting that the local immunity may interact with the ocular flora leading to a direct effect (44). In another study conducted on rats, oral antibiotic treatment reduced secretory IgA levels in tears (45). Immediately after birth, unaffected lacrimal B lymphocyte maturation in rats before opening the eyelids suggests that secretory IgA secretion can be regulated by other mucosal surfaces such as the intestine and nasal mucosa (46).

Unlike the T-lymphocyte-dependent pathway, microbiota in the lungs and intestines is known to mediate the class change in immunoglobulins over the Toll-like receptor (TLR) $(47,48)$. TLR activation leads to IgA class change by stimulating the release of B-lymphocyte-activating factor in epithelial and dendritic cells. The T-lymphocyte-independent pathway is important in protecting against intestinal pathogenic microorganisms. The effect of the ocular surface fluorescence on immunity is also via the T-lymphocyte-independent pathway.

This review aimed to compare the traditional culture methods for ocular microbiota with modern analysis methods such as 165 rDNA and BRISK, and also explore the interaction between ocular surface and ocular flora in the context of available studies. Fecaltransplantation-like ocular flora transplantation, personalized treatments, and ophthalmic microbiotics when planning antibiotic therapy are important to predict further plans in this regard.

\section{REFERENCES}

1. Gevers D, Kugathasan S, Denson LA, et al. The treatment-naive microbiome in new-onset Crohn's disease. Cell Host Microbe 2014;15:382-392.

2. Kostic $A D$, Gevers $D$, Siljander $H$, et al. The dynamics of the human infant gut microbiome in development and in progression toward type 1 diabetes. Cell Host Microbe 2015;17:260-273.

3. Smeekens SP, Huttenhower C, Riza A, et al. Skin microbiome imbalance in patients with STAT1/STAT3 defects impairs innate host defense responses. J Innate Immune 2014;6: 253262.

4. Zegans ME, Van Gelder RN. Considerations in understanding the ocular surface microbiome. Am J Ophthalmol 2014;158:420-422.

5. Tananuvat N, Salakthuantee K, Vanittanakom N, Pongpom M, Ausayakhun S. Prospective comparison between conventional microbial work-up vs PCR in the diagnosis of fungal keratitis. Eye 2012;26:1337-1343.

6. Taravati P, Lam D, Van Gelder RN. Role of molecular diagnostics in ocular microbiology. Curr Ophthal Rep 2013;1.

7. Endophthalmitis Vitrectomy Study Collabration. Results of the Endophthalmitis Vitrectomy Study. A randomized trial of immediate vitrectomy and of intravenous antibiotics for the treatment of postoperative bacterial endophthalmitis. Arch Ophthalmol 1995;113:1479-1496.

8. Gower EW, Keay LJ, Stare DE, et al. Characteristics of endophthalmitis after cataract surgery in the United States medicare population. Ophthalmology 2015;122:1625-1632.

9. Lee AY, Akileswaran L, Tibbetts MD, Garg SJ, Van Gelder $\mathrm{RN}$. Identification of torque teno virus in culture-negative endophthalmitis by representational deep DNA sequencing. Ophthalmology 2015;122:524-530.

10. Willcox MD. Characterization of the normal microbiota of the ocular surface. Exp Eye Res 2013;117:99-105.

11. Perkins RE, Kundsin RB, Pratt MV, Abrahamsen I, Leibowitz HM. Bacteriology of normal and infected conjunctiva. J Clin Microbiol 1975;1:147-149.

12. Dong $\mathrm{Q}$, Brulc JM, Iovieno $\mathrm{A}$, et al. Diversity of bacteria at healthy human conjunctiva. Invest Ophthalmol Vis Sci 2011; 52:5408-5413.

13. Graham JE, Moore JE, Jiru X, et al. Ocular pathogen or commensal: a PCR-based study of surface bacterial flora in normal and dry eyes. Invest Ophthalmol Vis Sci 2007;48: 5616-5623. 
14. Shin H, Price K, Albert L, Dodick J, Park L, Dominguez-Bello MG. Changes in the eye microbiota associated with contact lens wearing. mBio 2016;7:e00198-16.

15. Kaufman HE, Azcuy AM, Varnell ED, Sloop GD, Thompson HW, Hill JM. HSV-1 DNA in tears and saliva of normal adults. Invest Ophthalmol Vis Sci. 2005;46:241-247.

16. Campos MS, Campos e Silva Lde Q, Rehder JR, Lee MB, O'Brien T, McDonnell PJ. Anaerobic flora of the conjunctival sac in patients with AIDS and with anophthalmia compared with normal eyes. Acta Ophthalmologica 1994;72:241e245.

17. Capriotti JA, Pelletier JS, Shah M, Caivano DM, Ritterband DC. Normal ocular flora in healthy eyes from a rural population in Sierra Leone. International Ophthalmology 2009; 29:81e84.

18. de Caro JJ, Ta CN, Ho HK, Cabael L, Hu N, Sanislo SR, Blumenkranz MS, Moshfeghi DM, Jack R, de Kaspar HM. Bacterial contamination of ocular surface and needles in patients undergoing intravitreal injections. Retina 2008; 28:877e883.

19. Elander TR, Goldberg MA, Salinger CL, Tan JR, Levy B, Abbott $\mathrm{RL}$. Microbial changes in the ocular environment with contact lens wear. The CLAO Journal 1992; 18:53e55.

20. Ozkan J, Zhu H, Gabriel M, Holden BA, Willcox MD. Effect of prophylactic antibiotic drops on ocular microbiota and physiology during silicone hydrogel lens wear. Optometry and Vision Science 2012; 89:326e335

21. Stapleton F, Willcox MD, Fleming CM, Hickson S, Sweeney DF, Holden BA. Changes to the ocular biota with time in extendedand daily-wear disposable contact lens use. Infection and Immunity 1995; 63:4501e4505.

22. Ramachandran $L$, Sharma $S$, Sankaridurg $P R$, Vajdic $C M$, Chuck JA, Holden BA, Sweeney DF, Rao GN. Examination of the conjunctival microbiota after 8 hours of eye closure. The CLAO Journal 1995;21:195e199.

23. Hart DE, Hosmer M, Georgescu M, Farris RL. Bacterial assay of contact lens wearers. Optometry and Vision Science 1996;73:204e207.

24. Larkin DF, Leeming JP. Quantitative alterations of the commensal eye bacteria in contact lens wear. Eye 1991;5:70e74.

25. Muthappan V, Lee AY, Lamprecht $T L$, et al. Biome representational in silico karyotyping. Genome Res 2011;21:626-33.

26. Iskeleli G, Bahar H, Eroglu E, Torun MM, Ozkan S. Microbial changes in conjunctival flora with 30-day continuous-wear silicone hydrogel contact lenses. Eye and Contact Lens 2005;31: 124e126.

27. Gopinathan U, Stapleton F, Sharma S, Willcox MD, Sweeney DF, Rao GN, Holden BA. Microbial contamination of hydrogel contact lenses. Journal of Applied Microbiology 1997;82:653e658.

28. Mowrey-McKee MF, Monnat K, Sampson HJ, Smith CM, Davies GA, Mandt L,Proskin HM. Microbial contamination of hydrophilic contact lenses. Part I: quantitation of microbes on patient worn-and-handled lenses. The CLAO Journal 1992;18:87e91.
29. Baleriola-Lucas C, Fukuda M, Willcox MD, Sweeney DF, Holden $B A$. Fibronectin concentration in tears of contact lens wearers. Experimental Eye Research 1997;64:37e43.

30. Fleiszig SM, Efron N. Microbial flora in eyes of current and former contact lens wearers. Journal of Clinical Microbiology 1992;30:1156e1161.

31. Eder M, Farina N, Sanabria RR, Ta CN, Koss M, Samudio M, Cuevas C, Gines A, Simancas M, Klauss V, Mino de Kaspar H. Normal ocular flora in newborns delivered in two hospital centers in Argentina and Paraguay. Graefe's Archive for Clinical and Experimental Ophthalmology 2005;243:1098e1107. Albrecht von Graefes Archiv fur klinische und experimentelle Ophthalmologie.

32. Isenberg SJ, Apt L, Yoshimori R, Alvarez SR. Bacterial flora of the conjunctiva at birth. Journal of Pediatric Ophthalmology and Strabismus 1986;23:284e286.

33. Lee PW, Jun AK, Cho BC. A study of microbial flora of conjunctival sac in newborns. Korean Journal of Ophthalmology: KJO 1989; 3:38e41.

34. Sankaridurg PR, Markoulli M, de la Jara PL, Harmis N, Varghese $\mathrm{T}$, Willcox MD, Holden BA. Lid and conjunctival micro biota during contact lens wear in children. Optometry and Vision Science 2009;86:312e317.

35. Marcotte $H$, Lavoie MC. Oral microbial ecology and the role of salivary immunoglobulin A. Microbiology and Molecular Biology Reviews 1998;62:71e109.

36. Stroman DW, Roland PS, Dohar J, Burt W. Microbiology of normal external auditory canal. The Laryngoscope 2001;111:2054e2059.

37. Albietz JM, Lenton LM. Effect of antibacterial honey on the ocular flora in tear deficiency and meibomian gland disease. Cornea 2006;25:1012-9.

38. Ivanov II, Honda K. Intestinal commensal microbes as immune modulators. Cell Host Microbe 2012;12:496-508.

39. Wells PA, Hazlett LD. Immunocytochemical localization of immunoglobulins at the corneal surface of the mouse. Exp Eye Res 1985;40:779-96.

40. Pilette C, Detry B, Guisset A, et al. Induction of interleukin-10 expression through Fcalpha receptor in human monocytes and monocyte derived dendritic cells: role of p38 MAPKinase. Immunol Cell Biol 2010;88:486-93.

41. Chaudhuri J, Alt FW. Class-switch recombination: interplay of transcription, DNA deamination and DNA repair. Nat Rev Immunol 2004:4:541-52.

42. Casola S, Otipoby KL, Alimzhanov M, et al. B cell receptor signal strength determines B cell fate. Nat Immunol 2004;5:317-27.

43. Gill RF, Pirockinaite G, O'Sullivan NL, Montgomery PC. Nasal associated lymphoid tissue is not an absolute requirement for the induction of rat tear IgA antibody responses. Curr Eye Res 2010;35:1-8

44. Allansmith MR, Gudmundsson OG, Hann LE, et al. The immune response of the lacrimal gland to antigenic exposure. Curr Eye Res 1987;6:921-7. 
45. $\mathrm{Ng} \mathrm{KM}$, Ferreyra JA, Higginbottom SK, et al. Microbiotaliberated host sugars facilitate post-antibiotic expansion of enteric pathogens. Nature 2013;502:96-9.

46. Lin $\mathrm{M}, \mathrm{Du} \mathrm{L}$, Brandtzaeg $\mathrm{P}$, Pan-Hammarstrom Q. IgA subclass switch recombination in human mucosal and systemic immune compartments. Mucos Immunol 2014;7:511-20.
47. Ruane $D$, Chorny $A$, Lee $H$, et al. Microbiota regulate the ability of lung dendritic cells to induce IgA class-switch recombination and generate protective gastrointestinal immune responses. J Exp Med. 2016;11(213):53-7.

48. O'Neill LA, Golenbock D, Bowie AG. The history of Toll-like receptors -redefining innate immunity. Nat Rev Immunol 2013;13:453-60. 